\title{
Indirect translation on the London stage: terminology and (in)visibility
}

\author{
Geraldine Brodie* \\ Centre for Translation Studies, University College London, UK \\ *g.brodie@ucl.ac.uk
}

\begin{abstract}
Productions of translated plays on the London stage use a variety of terms to describe the interlingual interpretive process that has taken place between the source text and the performance. Most frequently, a translated play is described as a "version" or "adaptation", with the term "translation" reserved for specialized productions. The translation method most commonly adopted is to commission a source-language expert to prepare a "literal" translation which is then used by an English-speaking theatre practitioner to produce a playscript for performance. This article examines the incidence of such indirect translation practices, the inconsistencies of the applied terminology, and the relevance for indirect translation in its wider sense, revealing the shadows of translational behaviour even within language pairs, and demonstrating the multiplicity of agents impacting on the ultimate appearance of a text in translation.
\end{abstract}

Keywords: adaptation, literal translation, London theatre, theatre translation, version, indirect translation

\section{Introduction}

Translation is a collaborative exercise, incorporating a range of participants and stages in the trajectory between originating and ultimate texts. The romantic concept of the solitary, omniscient translator - Jerome, the patron saint of translators, alone in the desert with his bible and skull - is no longer apposite, if it ever were. The writer of the "letter of Aristeas" in around 130 BCE depicted seventy-two translators creating the early-third-century Septuagint translation of the Hebrew scripture, "making all details harmonize by mutual comparison" although this was disputed by later authors, who preferred to ascribe the translation of sacred texts to divine inspiration (Robinson 2014, 4-5). Our contemporary digital age, with its 
competing but complementary imperatives of globalization and localization, is, as Ji-Hae Kang points out, "developing into an intricate process that involves multiple mediators, or more specifically a network of humans and technological tools" $(2009,143)$. Even though such comparisons, mediators and networks have featured in the translation process from antiquity to the modern era, taking the form of sometimes simultaneous, sometimes sequential collaborations, the products of these extended processes may be regarded with some suspicion stemming from the perceived distance of their relationship with an originating text. When multiple agents, texts and languages intervene in the production of a target text, to what extent can that text be considered a "translation"? What are the appropriate theories, methodologies and terminologies that should be harnessed to examine and evaluate this phenomenon? Alexandra Assis Rosa, Hanna Pięta and Rita Bueno Maia, in an investigation of the concept of indirect translation in a recent special issue of this journal, observe that "indirect translation tends to be negatively evaluated because it arguably increases the distance to the ultimate source text and, therefore, is often hidden or camouflaged" $(2017,113)$. In this article, I contribute to the debate surrounding the implications of indirect translation by examining the applied procedures of translation taking place in London theatre today, where productions of plays originating in other languages are frequently performed using a text that has been created from an intermediary version. Although this practice does not exactly fit within Assis Rosa, Pięta and Bueno Maia's understanding of indirect translation as "a translation of a translation" (2017, 113), I argue that it resembles indirect translation activity in that the intermediate text represents a discrete step in the translation process.

Susanna Witt points out in her analysis of the indirect practice of podstrochnik interlinear intermediation in Soviet literary translation that "the entire transfer operation [is rendered] a translational hybrid involving an interlingual as well as an intralingual step" (2017, 167). Mediating theatrical translations differ from the "crude intermediate" of the podstrochnik in that they are distinct documents, commissioned from experts in language and theatre to support the composition of a theatrical playtext, and frequently detailed and well-informed texts in their own right. Witt's discussion, however, "proves the advantages of considering a flexible definition of indirect translation" (Assis Rosa, Pięta and Bueno Maia 2017, 126). In this vein, my article employs the concept of indirect translation to examine theatre translation practices and presents a view of the broader indirect translation process within the recognized field of translation activity, contributing to an understanding of the wider issues in indirect translation. Terminological and cultural issues concerning indirect translation predominate in the representation (or - more frequently - disguise) of translation on London stages. On the 
one hand, the construction of a translated theatrical text represents the collaborative nature of translation, in that the published text will generally conspicuously present the names of both the original playwright and the author of the performed text on the cover and provide information about further participating agents (directors, actors, designers) within. On the other hand, theatre translation processes provide evidence of "camouflaging" techniques in two respects: the performed product is rarely labelled a "translation"; and the existence of an intermediate "literal translation" by a specialist translator is frequently glossed over: relegated to the smallest credits or even ignored. My investigation of the incidences of this camouflage sheds light on the significance of the intermediate text within the translation process and queries the terminology operating to denote degrees of language and translation expertise: where they coincide, and where they diverge.

The theatre translation I inspect in this study contains two features that brush up against generally defined systems of indirect translation. The first is the presence of two, rather than three or more, languages in the process between source and target text. Like Witt, I argue that intralingual transposition should be included in the indirect translation process if the significance of the intermediary activity is to be fully explored; the section examining theatre terminology and indirect translation discusses definitions in more detail. The second feature is the heavy shadow cast over the intermediate "literal" translation, which is unpublished, unseen and may be (incorrectly) characterized as one of many drafts between the source and target text. As I maintain in the subsequent discussion of the (in)visibility of literal translation, this text is a viable translation in its own right, a targeted form of translation which can itself be used to query literal translation terminology and hypotheses. These two features, which distinguish theatre translation, open up indirect translation discussions for wider examination, considering variables that are relevant to indirect translation research: the type and the number of participants and languages in indirect translation processes. This article, therefore, by exploring translation activity and its terminological representation on the contemporary London stage, illustrates some of the complexities rehearsed by Assis Rosa, Pięta and Bueno Maia of establishing a terminology related to indirect translation (2017, 121-122). Can terminology be activated to shed light on a translational process passing through a succession of agents, or is the complex procedure of indirect translation doomed to obscurity by the very multiplicity of the agents involved?

The following section discusses the incidence of translated plays in London theatre, scrutinizing the translation terminology operated by theatres to describe plays in translation, and how far such terminology may assist in defining the concept and process of indirect 
translation, focusing on the tensions between translation and adaptation. This leads to an examination of the visibility of the "literal" translation, its significance as an intermediary text and the role of its translator in the progression of a play from source text onto target stage. Finally, I interrogate the efficacy of mapping terminologies onto theatre translation practices, and what such attempts reveal about the hierarchies of indirect translation. I argue that theatre translation terminology seeks to reflect the increasingly complex translation procedures taking place in theatre, and that indirect translation should be seen as an integral element within the wider study and practice of translation.

\section{Theatre terminology and indirect translation in London}

London's international position as one of the largest collections of theatre companies and places of performance makes the city's theatreland a productive site for the study of theatre translation. The Society of London Theatre, which represents major commercial and grantaided theatres, recorded box office attendances of 4,181,318 for "straight plays" (as opposed to musicals or other entertainment) in 2016 (Society of London Theatre 2017). The actual percentage of translations among such productions cannot be calculated accurately, the terminological issues discussed in this article being one of the features which render the capture of such information problematic. Within such constraints, I estimate - based on my own informal analysis of periodic snapshots comparing the percentage of translated plays with the total number of straight theatre productions on offer in London - that $12-14 \%$ of straight plays on an annual basis have a source that has been subjected to a translation process. My approximation differs from the research documented in the British Theatre Repertoire $2013^{1}$, which reports that "translations make up a very small part of the repertoire: the total number of original and revived translations still makes up barely one-tenth the number of original adult plays" (British Theatre Consortium, UK Theatre, and the Society of London Theatre 2015, 13). I attribute the difference to the fact that I draw my data from central London theatres, which are more likely to programme new work, rather than the national range. Either way, this represents a substantial corpus and compares favourably with the generally accepted figure of $3 \%$ of texts produced in translation in the Anglo-Saxon publishing industry (Venuti 2008, 12). London theatre translation procedures are not necessarily representative of practices in other English-speaking theatrical centres, or of dramatic translation between other languages. As Michelle Woods discusses, there is a widespread view that domesticating approaches are particularly prevalent in translation for the Anglo-American stage (2012, 8-17). Nevertheless, the extent and availability of research data in London theatre translation present the opportunity 
to scrutinize the processes currently in operation and identify contextual and procedural features that offer a revision of indirect translation activity more widely. This article draws and expands on data from my full-length study of eight translated productions in London (Brodie 2018), but also discusses further translational activity among the group of theatres and agents examined in that study. ${ }^{2}$

The interlingual interpretive process of creating productions of translated plays for the stage operates through a variety of routes, in London as elsewhere. However, the approach most commonly adopted by London theatres is to commission a source-language expert to prepare a "literal" translation which is then used by an English-speaking theatre practitioner to produce a playscript for performance. I argue that this process should be included within a broad definition of indirect translation because a distinctive intermediate translation is required. However, the application of the term "indirect" translation to describe this theatrical practice requires the second step of the process (between the intermediary translation and the target text) also to be recognized as translation. For support, I draw on Jakobson's three categories of translation $(2012,127)$, which are amply represented in the theatre in various linguistic aspects of the transfer process. "Intralingual" rewording is carried out between a literal translation and a text for performance by the commissioned writer and also by a wider group of theatre practitioners in the rehearsal and development phases; "translation proper" is conducted by the literal translator or a linguist-playwright who commands the source and target languages; "intersemiotic" translation, the "interpretation of verbal signs by means of signs of nonverbal sign systems", takes place constantly in theatre, from the performance of textual stage directions, through interpretive gesture, to the replacement of excised text by mime, stage properties and many other forms of theatrical activity, as Kate Eaton documents in her characterization of the rehearsal room as translation "laboratory" $(2012,172)$. Nevertheless, this interpretation of "indirect translation" goes against those definitions that stipulate a movement between three languages, such as Mark Shuttleworth and Moira Cowie's procedure whereby a text is translated "via an intermediate translation in another language" $(2014,76)$ or Harald Kittel and Armin Paul Frank's identification of an indirect translation based on a source "which is itself a translation into a language other than the language of the original, or the target language" (1991, 3).

It might be argued that all theatrical translation by a specialist linguist-playwright should be labelled "translation", with any other type of refraction identified by a different term and excluded from translation studies research. Furthermore, there is no conclusive term for "not a translation but in some way moving between languages". The most popular option, 
"adaptation", includes translation while extending into the further reaches of intersemiotic transfer: in her study of the theory of adaptation, Linda Hutcheon identifies a continuum of adaptation, with literary translation at one end, "in which fidelity to the prior work is a theoretical ideal, even if a practical impossibility", and at the other end, spin-offs, expansions (sequels, prequels), fan zines and slash fiction (2013, 171-172). While most observers would agree that the latter end of the scale would not qualify as translation, at which point on the continuum would translation cease to take place? As Katja Krebs observes, the theatrical practice of rewriting "blurs the boundaries between adaptation and translation", the question of nomenclature depending on "the legal, ideological, and hierarchical status of the practitioners involved" $(2012,46)$. Even if translation takes place without the use of a literal translation, because the writer of the performance text is familiar with the language of the source playtext, the conflict between translation and adaptation labelling remains. Setting aside issues of cultural transposition and artistic interpretation, this may be because practical staging requirements (the dimensions of the performance space, the budget availability for cast numbers, durational constraints on performance time, for example) result in substantial divergences from the source text. Or a differentiated translation may be required because the text selected for production has been staged in another translation on a previous occasion. Such factors apply to a translated performance text whether or not it has been created by an indirect route.

In London theatre, the terminology used to describe a translated play seems to be proliferating rather than consolidating around a core lexis. The labels attached to translated plays performed on the London stage are remarkable in their variety and creativity. "Free adaptation", "revised by", "based on", "English text by", “a modern take on", "a remix of" have all recently been applied by theatres to denote new productions of playtexts that originated in a language other than English. This vocabulary, not forgetting the more frequently found terms "adaptation" and "version", demonstrates the difficulties in isolating fixed definitions of key terms in translation for the theatre, and then associating those terms with specific, and differentiated, translation activities. In fact, the most regular description used is "new", in itself an indicator of the efforts by agents operating within the theatre translation field to distinguish each work of translation from its precedents and competitors. To label a production "an indirect translation of" would run counter to such neophilism, and this terminology is not found. Nevertheless, productions regularly reach the London stage via an intermediary translation, one of the hallmarks of indirect translation, although in most cases only two languages are involved. The examination of the relationship of the intermediary or literal translation within 
theatrical terminologies for translated plays necessitates the query of the stability of translation typologies, and is therefore simultaneously an investigation of the nature of indirect translation.

Theatre grapples with the translation/adaptation dichotomy by introducing additional terms, in particular "version". This may be used to represent an intermediate point along the continuum between translation and adaptation, more creatively interpretive than a morphologically close translation but less inclined to reconstruction than an adaptation. However, despite raising this issue during research interviews with theatre practitioners (Brodie 2018, 105-154), I have not been able to establish a consensus as to the appropriate usages for these terms; most saw a version as sitting between a translation and an adaptation, but a few responders considered a version to be a further departure from the source text than an adaptation, creating a product that belonged more decisively to the target writer. The playwright and adaptor Tanya Ronder considers that the label applied to "any English rendition of a foreign-language play ... is simply an agreement reached between writers, theatres, agents and estates ... a sliding scale of categories with no real absolutes" (2017, 203). An additional complication arises when the terms applied to a single translation change according to context. The 2004-2005 production of Friedrich Schiller's Don Carlos, the performance text for which was written by the translator and adapter Mike Poulton, was labelled a "translation" in the original programme for the Sheffield Theatres $(2004,1)$, a "version" in the published text (Schiller 2005) and an "adaptation" in the revised programme published for the transfer of the production to the Gielgud Theatre in London (2005). The text itself did not change for these iterations. These terminological transpositions were the subject of discussion between the participants (Brodie 2013, 124) and reflect the reception of the translation as much as the agency of the translator, as I discuss later in this article. This flexibility, along with the proliferation of additional nomenclatures, suggests that theatre practitioners continue to search for an adequate terminology that will accurately reflect the development of a translation for the stage.

Notwithstanding the variations discussed above, the most frequent terminology attached to a translated play is that of "version" or "adaptation". The translated text may well be an indirect translation created through a literal translation, but, whether or not this is the case, it is likely to be a reworking of a source text that has previously been translated, possibly by different individuals for different productions. The range of translated plays within the English-speaking repertoire in London, especially in the larger theatres, tends to be confined to a generally-accepted canon. Gunilla Anderman identifies Anton Chekhov and Henrik Ibsen as "honorary British dramatists" with August Strindberg and Federico García Lorca waiting 
their turn $(2006,8)$. A fairly small coterie of European playwrights is represented on a regular basis on the London stage, although this may be disrupted from time to time by a periodic focus on less commonly-translated genres and/or writers. For example, Spanish Golden Age seasons were produced by the Royal Shakespeare Company in 2004 and co-produced by the Arcola Theatre, the Theatre Royal Bath and the Belgrade Theatre in 2014, bringing the works of sixteenth-century playwrights such as Pedro Calderón de la Barca, Lope de Vega and Tirso de Molina to the stage. The 2004 Don Carlos production mentioned above was the forerunner for further productions of Schiller's works over the next few years, such as Mary Stuart and Luise Miller at the Donmar Warehouse Theatre in 2009 and 2011. It is notable that these less familiar, and therefore potentially more risky, productions were initiated partly outside London: Stratford-upon-Avon, Bath and Coventry in the case of the Golden Age, and Sheffield for Schiller's Don Carlos. Theatres with large numbers of seats to fill tend to opt for reliable choices. Jack Bradley, literary manager of the Royal National Theatre in London (generally identified as the National Theatre) from 1994 to 2007, points out "one striking fact": of fortyone plays translated from a foreign language and produced in the theatre during the 1995 to 2006 seasons, only one was written by a living writer, Life X 3 by Yazmina Reza $(2011,192)$. In this context, the retranslation of a familiar play needs to make a case for itself as different from preceding productions, particularly when those productions have been staged during the previous twelve months, as was the case for Chekhov's The Seagull, discussed below, or Aeshylus's Oresteia, shown in Rory Mullarkey's “adaptation” at Shakespeare's Globe Theatre and Robert Icke's "version" at the Almeida Theatre, both in 2015. Thus "version" and "adaptation" may indicate the indirect method of translation, and/or the position of the translated text within the theatrical canon, and/or the expectation on the part of the promoters of a production of the extent of the audience's "knowingness" - that "conceptual flipping back and forth between the work we know and the work we are experiencing" (Hutcheon 2013, 139). These terms recognize the complex status of translation within the theatrical system, but do not function reliably as markers of the type of translation process conducted with regard to a particular text.

If "version" and "adaptation" cannot be relied upon to signal a specific method of translation, how firmly is the term "translation" itself applied? Broadly, this usage tends to be reserved in London for the translation of texts for the first time or in specialist theatres. One such example is the Royal Court Theatre, which locates itself as "the leading force in world theatre for energetically cultivating writers - undiscovered, new, and established" (2016) and is likely to stage the English-language premieres of contemporary plays, or works which have 
never previously appeared in English, for example, Fireworks (Al'ab Nariya) by the Palestinian poet and playwright Dalia Taha; this play was written during a residency organized by the Royal Court Theatre as part of their International Playwrights project, and translated, for production in 2015, from Arabic by Clem Naylor, a professional translator who also contributed several literary translations to an anthology of short stories from Saudi Arabia (AlSebail and Calderbank 2012). In addition to unconventional new work of this nature, retranslations are also produced at the Royal Court Theatre, such as Eugène Ionesco's Rhinoceros (translated by the experimental playwright Martin Crimp) and Max Frisch's The Arsonists (translated by the political satirist and writer Alistair Beaton) in 2007. These are also billed as "new" translations, and theatre practitioners with linguistic expertise - in addition to their professional affinity for the text in question - are commissioned to create the translated texts, using the direct method of translation. On the rare occasion that the Royal Court adopts the indirect method of translation, as for The Seagull, it is identified as a "version". The Royal Court Theatre seems consistent both in its use of the term translation and in the priority it gives to the direct method of linguistic transfer. This theatre is, however, unusual in this regard (Brodie 2012); furthermore, translators who are commissioned by the Royal Court also work for other theatres, where their translation practices may be less clearly defined, as I discuss below in relation to the playwright, translator and adaptor Martin Crimp.

The Royal Court Theatre is run as a not-for-profit organization by the English Stage Company Limited, a registered charity. This profile is a regular feature of theatre companies commissioning translated productions: they tend to operate outside the commercial theatre sector, whatever the translation method or terminology adopted. I attribute this to the fact that translated plays are more resource-intensive, requiring time and funding to arrange the translation process. Larger subsidized theatres are more likely to be endowed with such organizational resources. In spite of this provenance, the use of high-profile writers for indirect translation is often seen as commercially motivated. Susan Bassnett voices the suspicion that market-force economics are the principal motivation: "the key factor is the size of the audience and the price they are willing to pay for tickets, certainly not the ethics of translation" (1991: 102). The corollary of this conclusion is that the act of translation is sub-divided and downgraded for commercial reasons and that theatre translation consequently suffers some reputational loss. However, the dividing line between commercial and subsidized theatre is as unclear as that between translation and adaptation. London theatre is a financial hybrid with most organizations dependent on a mix of state subsidy, private donations and commercial investment for profit. Heavily state-subsidized entities such as the National Theatre must show 
a return on investment to their public funders in the same way as the commercial theatreowning groups such as the Ambassadors Theatre Group are required by their shareholders to meet their financial covenants. However, the measurement of returns in the public sphere can be defined according to a wider range of parameters. Commercial theatre organizations may benefit from a degree of indirect state support in the form of tax advantages via their use of charitable trusts for heritage property conservation. It is an over-simplification therefore to see translation approaches delineated according to commercial versus not-for-profit motives. The imperative to fill seats is pressing for the vast majority of theatres, whatever their source of funding, so that the chosen method of translation and terminology depends on a variety of factors that goes beyond funding mechanisms and ticket sales. Therefore, any attempt to associate direct translation with subsidized theatre while attributing the indirect method to commercial motives meets with difficulties when studying the trajectory of a translated production. The decision to create a performance text via a literal translation, an indirect method of translation, is made for a wide range of reasons, endowing the intermediate text with significance for the whole translation process. As James St André points out (in relation to the translation of a translated text, which he labels "relay"), the fact that translation through an intermediary text is "seen, at best, as a necessary evil", which is responsible for mistakes and distortions, only serves to demonstrate "the extent to which the devaluation of translation has been internalized within the translation community itself' $(2009$, 232). Theatrical terminological experimentation, and the reluctance to categorize interlingual movement as "translation", could be seen as an illustration of such devaluation, but it may also point to an effort to reaffirm the creative element of the extended translation process and to recognise the multi-agency of translation. In theatre as in indirect translation theory, terminological flexibility opens a space for the reassessment of the translation process.

\section{London theatre practices: the (in)visibility of literal translation}

Although the indirect method of translation is the most-practiced option for translated plays intended for London theatre, there is little awareness of this procedure outside the academic and practising theatre translation community. As I have discussed, this is partly due to the lack of precision in terminology. However, it may also be attributed to the imbalance of cultural capital between the indirect and literal translators. The visibility of the intermediate literal translation, like the intermediate text and language in more broadly defined indirect translation, tends to be obstructed by the public-facing text and its author. When the indirect method is 
applied, it is common practice to commission a familiar name to be attached to the staged translation. The translating name will usually be that of a playwright, director or another literary practitioner who has a track-record in commercially and critically successful productions. If the named writer is not an expert in the source text language, he or she will be provided with a literal translation, which may be an extant translation from an earlier production or a published literary translation. However, if the production budget is sufficiently accommodating, a new literal translation will be commissioned from a translator who provides substantial notes on linguistic, cultural and theatrical features in the text. One example is the National Theatre production of Lorca's The House of Bernarda Alba in a "new English version" by David Hare. Simon Scardifield is acknowledged as the literal translator in the theatre programme, and Hare states in his "Adaptor's Note" prefacing the published text that "[t]his new version is based on a literal translation by Simon Scardifield" (García Lorca 2005a, vi). However, only Hare's name is displayed alongside that of Lorca on the cover of these two publications. Information about the intermediary literal translation and its translator is thus secondary in the translation hierarchy, in a recognizable marker of indirect translation more generally. Nevertheless, the two-step translation process for this production is prominently displayed, with further detail of the mechanism of the translation readily available. In this case, indirect translation is not in disguise.

The translation process is not always so publicly documented. Acknowledgement of the role of the intermediary translator varies, both within theatres and in relation to different works by the same named translator. As with terminological usage, there does not appear to be a consistent policy applied even in relation to specific individuals or organizations (probably with the exception of the Royal Court Theatre, discussed above), and certainly not for the theatre industry as a whole. It would seem that the extent of acknowledgement depends on the readiness of practitioners in a position of influence and with an interest in the procedure to highlight the detail of their activity. I have observed that David Hare consistently credits his literal translators, the best example of good practice being the programme for his "version" of Maxim Gorky's Enemies for the Almeida Theatre in 2006. In this case, the literal translator Charlotte Pyke was named immediately below Hare in the cast list, above the other actors and creative staff, and her photograph and biographical details were displayed on the same doublepage spread as Hare, the director, the designer and other creative contributors to the production (Almeida Theatre 2006). Such recognition is rare.

It is still the case that no reference may be made to a literal translation, even when a production text is labelled a version or adaptation, and we are left wondering on which 
source(s) the writer depended to create the performed playtext. It is possible that a range of translations was consulted, and this is particularly likely for contemporary productions of Classical Greek drama such as the two very different versions of Medea which were performed in 2015 at the Almeida Theatre and the Gate Theatre Notting Hill. The former, in a "new version" by the novelist Rachel Cusk, attributed the play to Euripides, but presented a focus on the eponymous central character that chimed with the searing dissections of motherhood and divorce which characterized Cusk's memoir charting the disintegration of her own marriage (2012). The latter production, co-written by Kate Mulvaney and Anne-Louise Sarks, originally for the Belvoir Theatre, Sydney, was portrayed from the perspective of Medea's children, who are locked in their bedroom while they listen for the sounds of their parents' destructive behaviour. Sarks explained in a post-show discussion that the production had largely been developed through improvisation workshops with the actors playing the children, and that she and Mulvaney had read around the Medea myths in preparation for their development of the production. ${ }^{3}$ Such procedures are resonant of another sub-set of indirect translation: compilative translation (as discussed by, for example, Jiři Levý 1969, 162). In such cases, the compilation of a range of sources is a preferred creative methodology, permitting the writers to develop their own approach to the source within a wider context of receptions. It is, in fact, rare in a theatrical retranslation for only one intermediary translation to be consulted. Writers complain that their versions are queried by actors and directors in rehearsal, on the basis of other translations that they have read in preparation. Martin Crimp has said in this respect that his plan is "to go into a rehearsal room with a non-negotiable document" (Crimp and Sierz 2016, 114). The writer's new text thus supersedes its predecessors, and becomes the predominant source for that production. Thereafter it will join the collection of translations emanating from the original source text. Some translations are revived; for example, the poet Ted Hughes's 1998 version of Racine's Phèdre was posthumously given a new production at the National Theatre in 2009. However, the transitory nature of the very limited spotlight on such texts may explain the priority given to foregrounding the name of the author of the latest version, at the expense of the literal translator.

Even when recognized, the literal translator frequently has to be sought among the smaller credits while the English-speaking playwright shares the limelight with the source-text author. This imbalance is usually also reflected in the pecuniary rewards for the translation exercise in addition to the variance in the degree of involvement of the indirect and literal translators in the development of the production. Literal translators are paid a one-off fee ${ }^{4}$ for which the theatre purchases substantial rights in the translation. Contractual agreements are 
usually private matters, inaccessible to researchers. However, the National Theatre has developed a template contract for literal translators that is also used as a model by other theatre practitioners, on occasion. ${ }^{5}$ This template makes it clear that the translation will not be performed, but will be used for reading and consultations within the National Theatre and may be used as a basis by a writer commissioned by the National Theatre to write a version of the original play. The theatre also retains the rights to license other writers to use the literal translation for work commissioned by the National Theatre. All other rights in the translation, however, remain with the literal translator. In addition to the fee, the literal translator receives a credit in the programme for the performed play and two complimentary tickets for press night. This contract indicates the strategic significance of the literal translation in the theatrical dramaturgical process. The contractual obligation to credit the literal translator also demonstrates the National Theatre's recognition of the creative contribution of the literal translator. The drafting of the rights clauses within the contract provides further evidence of the blurring between translation and adaptation and their respective ownerships: the literal translator is specifically requested to agree and accept that "a stage version by another writer might contain echoes of the Literal Translation" and that the literal translator will not make any claim against the National Theatre or its commissioned writers in respect of versions and adaptations stemming from the literal translation. This documents the potential influence of the literal translation upon the subsequent writer. The echoes of the intermediary in an indirect translation may be easier to identify in an intralingual theatrical translation process, but this contractual acknowledgement has significance for indirect translation more generally.

The explicit acknowledgement of the literal translator's role evidenced by the National Theatre's contract (and the willingness to share it with me, a researcher) is an example of how this theatre aims to formalize ethical theatrical practice. Such transparency may not always be apparent. As with other forms of indirect translation, the incidence of a mediating translation may be hidden, especially where it concerns the identity of the intermediary translator. The multiplicities of theatre terminologies circulating around translation may at least indicate the fact that a two-step indirect process has taken place (although, again, not consistently, as we saw with Don Carlos). Translators who engage in the literal stage of the process, nevertheless, can feel "cynical and discouraged about the position of the much-underrated literal translator", according to Helen Rappaport, the author of at least twelve literal translations for theatre from Russian $(2007,75)$. William Gregory, the translator of many Spanish-language plays for the Royal Court Theatre, among others, will only exceptionally agree to provide a literal translation because, as he wrote to me in an email on 7 September 2016, "I became a theatre translator in 
the first place because I wanted to translate directly for the stage; doing a literal doesn't afford me that creative pleasure". Nevertheless, the preference for commissioning a fresh literal translation to support a new English-language version of an established classic play demonstrates the integral place of the literal translation in the theatre translation process and the theatrical validation of linguistic expertise and judgement on a renewable and current basis.

The literal translation has not come into such extensive use merely as a result of the perceived monolingualism of British theatre. English-speaking playwrights who command second and subsequent languages do exist, and are commissioned to work on direct translations. Christopher Hampton, Martin Crimp, Caryl Churchill and Timberlake Wertenbaker all translate from French, for example. Even so, their translations may well be publicized as versions or adaptations, and their knowledge of the source language does not necessitate the omission of the literal translation step. As the Italian-speaking writer Mike Poulton explains:

Where I am competent in the language I am to work in, I make my own literal translation before beginning the serious, and lengthy, business of adaptation. In languages where I am not competent - most of them - I commission a literal translation. (2005, xiii)

The literal translation is not a first draft, but an essential source for a playwright who does not speak the original language to create a performable play. In addition to preparing a close but intelligible version of the original, the literal translator provides substantial notes on the content and context of the source language text. Literal translations are rarely available for study as they are not published texts and were originally composed for "an audience of one", as Agnes Broomé has noted in relation to her own literal translations for the playwright Howard Brenton (2013). Restricted access to such texts is the inevitable result, but literal translations are retained in theatre archives and literary departments for potential future use, and can be made available on request. As stipulated in the National Theatre contract, literal translations may be re-used for subsequent versions. This is less a matter of obfuscation of the process, therefore, than an expectation of a limited audience for the product. Scardifield's translation of The House of Bernarda Alba for David Hare, for example, can be obtained from the National Theatre Archives, and provides good evidence of the motivation of such a text in the balance between dialogue and commentary: 227 footnotes in a 47-page document (García Lorca 2005b). Literal 
translators are very clear as to the purpose of their translation, even if disappointed by their own lack of visibility (and level of remuneration).

The theoretical debate around this topic has a tendency to look askance at the incorporation of literal translation within theatre practices. Joseph Farrell, for example, adopts the term "surrogate translator" to describe the writer of the performed translation, and takes the dismissive view that such a figure "has no more knowledge of the culture he is handling than has a dilettante with a metal detector of the Roman treasure trove his machine has uncovered" (1996, 54). The editors of the volume Theatre Translation in Performance reinforce this approach, writing in their introduction, "the coalescence of writing and translating as a secondary practice within a two-step translation process only enhances playwriting with no interlingual and little intercultural awareness, while downplaying 'actual' translation" (Bigliazzi, Kofler, and Ambrosi 2013, 12). In the same volume, Cristina Marinetti complains that translation, defined as "the interlingual transfer of dramatic text", is "becoming obsolete" in British theatre, because the "focus on performability" and "widespread use of monolingual playwrights as translators" has shifted the notion of theatre translation "radically away from something that has primarily to do with language" $(2013,32)$. Practitioners, however, take a more pragmatic view of the procedure. Simon Scardifield enjoys providing notes and background information: "the fun of it lies in the slightly nerdy, pernickety thoroughness", he reflects, adding, "I solve problems, and that's satisfying" (in Brodie 2018, 140). It is understood that a literal translation is not intended to be staged: its function is to contribute to the creation of a performable production. Literal translators tailor their translating approach in accordance with the purpose of the commission. Similarly, translator/playwrights, for example Martin Crimp and Christopher Hampton, are prepared to take on the role of indirect translator, when required; both created versions of Chekhov's The Seagull, for the National Theatre and Royal Court Theatre respectively, in 2006 and 2007, in each case using a newly commissioned literal translation (from Helen Rappaport for the National Theatre and Vera Liber for the Royal Court Theatre). This procedure suggests that a fresh literal translation is a desirable requisite, commissioned whenever funds permit. The debate around the literal translator's role relates not to the value of the linguistic intervention, which is implicitly acknowledged, but rather to the degree of status and visibility that is accorded to these practitioners and their contribution to the performed translation. Similar conditions are found with regard to the intermediary translation (and language) in multilingual indirect translation. The importance and influence of the intermediary document is evidenced by the nature of that language - often a key pivot language (English, German, Russian) whose traces left in the final-stage text render the cultural 
transfer a complex and hybrid operation, subject to what James Hadley has dubbed "the concatenation effect" whereby the variances in ideological stance of the successive translators modify cultural specificities as the translation process takes place (2017, 183-197).

The literal translation is a targeted piece of work. It stands alone, but also performs a crucial bridge between the source text and the performed translation. The actor and translator Charlotte Pyke considers that the original author is undermined if the literal translator is not credited because there is otherwise "no recognition of the transition" between the range of writers in the whole translation process (in Brodie 2018, 145). Making the process visible validates all the contributory agents and binds them together into a team. The expert theatrical literal translator provides an example of how indirect translation may add the value of collaboration to the extended translation process. In my opinion, any reluctance to accept a two-stage translation process as "translation proper" overlooks the sometimes complex relationship between linguistic competence and expertise in translation. An accomplished linguist is not automatically a gifted translator. On the other hand, an expert translator in a particular language pair may be aware of the issues that need to be taken into account in transfers from other languages into his or her mother tongue. As I have analysed elsewhere, the playwright, translator and adaptor Martin Crimp's writing for theatre demonstrates an awareness of a theory of translation that can be extrapolated from his composition, translation and adaptation activity, such that "Crimp's authorial presence exists throughout his work, whether self-authored, translated or adapted, while simultaneously operating to recognize the plurality of voices within a translated text" (Brodie 2016, 94). This leads us back to a consideration of the boundaries between translation and adaptation. To what extent can the creation of a new work with the aid of a literal translation, whether translated by the target text writer or another expert linguist, be classified as a translation? In such circumstances, the intermediary literal translation and translator are contributors to, and collaborators in, the linguistic movement of text from the source to the target culture resulting in a performed translation. In the same way, how is the final text in a multilingual indirect translation distinguishable from an adaptation? Moving through a series of distinct forms it is both distanced from and attached to the starting text by means of the language and culture of the intermediary translation. Theatrical translation provides an illustration of the strategic significance of all the steps in the indirect translation procedure, and makes a case for valuing the transparency of the process.

\section{Conclusion: Mapping indirect translation}


The categorization of indirect translation processes is a complex and at times controversial area of translation studies, as Assis Rosa, Pięta and Bueno Maia demonstrate (2017, 113-132). Terminological and ideological aspects of these debates are reflected in the variability of current theatrical translation/version/adaptation terminology, which cannot be neatly mapped onto the direct/indirect translation procedures taking place. These terminological proliferations, however, signal the variety of approaches to translation in the theatre and indicate that indirect translation is itself too diverse an activity to be labelled by a single term. Investigating the variances between the terminology and the processes highlights the relevance of agency and contextual factors within theatrical translation which may assist in theorizing translation more generally. Any view that only the interlingual code-shifting process is "translation proper" is challenged by theatrical terminology. Theatrical practice implicitly queries the supremacy of the term "translation", demonstrating by its indeterminate terminology that the transformative shift from one language to another proceeds through a variety of phases and agents. Blossoming theatre terminology seeks to recognize these complex processes. Labelling an indirect, or indeed a direct, translation as an adaptation/version/revision/modern take/remix signals the collaborative and creative activity that has taken place in bringing the production to the stage. The literal translator is among those contributors. Recognising adaptations as translations acknowledges the crucial role of the collaborators, and the complex process that constitutes translation.

Theatre presents a multifaceted site for the study of translation, particularly with regard to the visibility of translation in transporting a source text to a target audience. Theatre's tendency to publicise a translating agent alongside the author of the source text renders the translational act more visible, while the performance of the text itself displays the collaborative theatrical procedures that shape the text for transmission. These visibilities are, however, undermined by procedural and participational obscurities. Literal translators suffer from both these opacities: their collaborative input is generally out of sequence with other practitioners and therefore overlooked during the pre-performance preparation, and accorded minor acknowledgement in public documentation. The terminology used only serves to render the process more unclear. Nevertheless, theatre practitioners themselves recognize the value of the literal translation. Multiple terminologies suggest that the theatre industry is searching for the means to describe translation practices that indicate and provoke a recognition of collaborative activity. Even though the visibility of individual agents may be limited, shifting vocabulary reminds the receiving audience to question the genesis of what they are seeing, prompting them to recall that they are witnessing an act of interpretation. The intermediate literal translation is 
a discrete and viable component within the translation procedure, and deserves to be valued for itself and its contribution to the wider process and study of indirect translation.

\section{Notes}

1. The report was researched and written by David Brownlee, David Edgar, Wendy Haines, Clare Ollerhead and Dan Rebellato, members of the British Theatre Consortium, a research group of playwrights and academics (British Theatre Consortium, UK Theatre, and the Society of London Theatre 2015, 46).

2. The Translator on Stage investigates the translation processes from commission to reception of eight productions on the mainstream London stage in 2005. Data gathered for the study includes published playtexts, critical literature, non-published archival materials, financial statements, production reviews and interviews conducted by the author with the agents. This article draws on certain information regarding productions, agents and theatres discussed in further detail in the book, including Friedrich Schiller's Don Carlos in a version by Mike Poulton, Federico García Lorca's The House of Bernarda Alba in a version by David Hare, the Almeida Theatre, the Royal Court Theatre and the Royal National Theatre.

3. My own notes, post-show talk, Gate Theatre, Notting Hill, 5 November 2015.

4. Amounts vary between practitioners and theatres, but are likely to be in the range of $£ 500-£ 1,500$ for a new literal translation.

5. I gratefully acknowledge the cooperation of Emily McLaughlin, New Work Department, National Theatre, in arranging for sight of a current template contract on 7 September 2016.

\section{Disclosure statement}

No potential conflict of interest was reported by the author.

\section{Note on contributor}

Geraldine Brodie is Senior Lecturer in Translation Theory and Theatre Translation at University College London. Her research centres on theatre translation practices in contemporary London. Recent publications include Adapting Translation for the Stage, coedited with Emma Cole (Routledge 2017) and her monograph The Translator on Stage 
(Bloomsbury 2018) She is a Panel Associate of ARTIS (Advancing Research in Translation and Interpreting Studies) and a Senior Fellow of the Higher Education Academy.

\section{References}

Almeida Theatre. 2006. Enemies [Theatre Programme]. London: Almeida Theatre.

Al-Sebail, Abdulaziz and Anthony Calderbank, eds. 2012. New Voices of Arabia - the Short Stories: An Anthology from Saudi Arabia. London: I. B. Tauris.

Anderman, Gunilla. 2006. Europe on Stage: Translation and Theatre. London: Oberon.

Assis Rosa, Alexandra, Hanna Pięta and Rita Bueno Maia. 2017. "Theoretical, Methodological and Terminological Issues Regarding Indirect Translation: An Overview.” Translation Studies, 10 (2): 113-132.

Bassnett, Susan. 1991. "Translating for the Theatre: The Case against Performability." Traduction, Terminologie, Rédaction: Etudes sur le texte at ses transformations, 4 (1): 99-111.

Bigliazzi, Silvia, Peter Kofler, and Paola Ambrosi. 2013. "Introduction." In Theatre Translation in Performance, edited by Silvia Bigliazzi, Peter Kofler and Paola Ambrosi, 1-26. Abingdon: Routledge.

Bradley, Jack. 2011. "Not Lost in Translation.” In Staging and Performing Translation: Text and Theatre Practice, edited by Roger Baines, Cristina Marinetti and Manuela Perteghella, 187-199. Basingstoke: Palgrave Macmillan.

British Theatre Consortium, UK Theatre, and the Society of London Theatre. 2015. British Theatre Repertoire 2013. Accessed $18 \quad$ July 2017. http://britishtheatreconference.co.uk/wp-content/uploads/2015/05/British-TheatreRepertoire-2013.pdf.

Brodie, Geraldine. 2012. "Theatre Translation for Performance: Conflict of Interests, Conflict of Cultures". In Words, Images and Performances in Translation, edited by Brigid Maher and Rita Wilson, 63-81. London: Continuum.

Brodie, Geraldine. 2013. "Schiller's Don Carlos in a Version by Mike Poulton, Directed by Michael Grandage: The Multiple Names and Voices of Translation." In Authorial and Editorial Voices in Translation Volume 1: Collaborative Relationships between Authors, Translators, and Performers, edited by Hanne Jansen and Anna Wegener, 119-140. Montréal: Éditions Québécoises de l'CEuvre.

Brodie, Geraldine. 2016. "The Sweetheart Factor: Tracing Translation in Martin Crimp's Writing for Theatre." Journal of Adaptation in Film \& Performance, 9 (1): 83-96. 
Brodie, Geraldine. 2018. The Translator on Stage. New York: Bloomsbury.

Broomé, Agnes. 2013. "An Audience of One - Literal Translation for a Playwright” [Seminar abstract]. Accessed 18 January 2015. http://www.ucl.ac.uk/translation-studies/theatretranslation-forum/past-forums/naturalism.

Crimp, Martin and Aleks Sierz. 2016. "UCL Guest Session: Attempts on His Life - Martin Crimp - playwright, translator, translated." Journal of Adaptation in Film and Performance, 9 (1): 101-116.

Cusk, Rachel. 2012. Aftermath: On Marriage and Separation. London: Faber and Faber.

Eaton, Kate. 2012. "Turnips or Sweet Potatoes...?" In Translation, Adaptation and Transformation, edited by Laurence Raw, 171-187. London: Continuum.

Farrell, Joseph. 1996. “Servant of Many Masters.” In Stages of Translation, edited by David Johnston, 45-55. Bath: Absolute Classics.

García Lorca, Federico. 2005a. The House of Bernarda Alba, in a version by David Hare. London: Faber and Faber.

García Lorca, Federico. 2005b. The House of Bernarda Alba, translated by Simon Scardifield. London: Faber and Faber.

Gielgud Theatre. 2005. Don Carlos [Theatre Programme]. London: Gielgud Theatre.

Hadley, James. 2017. "Indirect Translation and Discursive Identity: Proposing the Concatenation Effect Hypothesis.” Translation Studies, 10:2, 183-197.

Hutcheon, Linda. 2013. A Theory of Adaptation. $2^{\text {nd }}$ ed. London: Routledge.

Jakobson, Roman. 2012. "On Linguistic Aspects of Translation." In The Translation Studies Reader, $3^{\text {rd }}$ ed., edited by Lawrence Venuti, 126-131. Abingdon: Routledge.

Kang, Ji-Hae. 2009. "Institutional Translation.” In Routledge Encyclopedia of Translation Studies, $2^{\text {nd }}$ ed., edited by Mona Baker and Gabriela Saldanha, 141-145. Abingdon: Routledge.

Kittel, Harald and Armin Paul Frank. 1991. "Introduction. Indirect Translation in EighteenthCentury Germany." In Interculturality and the Historical Study of Literary Translations, edited by Harald Kittel and Armin Paul Frank, 3-4. Berlin: Erich Schmidt.

Krebs, Katja. 2012. "Translation and Adaptation - Two Sides of an Ideological Coin." In Translation, Adaptation and Transformation, edited by Laurence Raw, 42-53. London: Continuum.

Levý, Jiři. 1969. Die literarische Übersetzung [Literary Translation]. Translated by W. Schamschula. Frankfurt am Main: Athenäum Verlag. 
Marinetti, Cristina. 2013. "Transnational, Multilingual, and Post-dramatic: Rethinking the Location of Translation in Contemporary Theatre." In Theatre Translation in Performance, edited by Silvia Bigliazzi, Peter Kofler and Paola Ambrosi, 27-37. Abingdon: Routledge.

Poulton, Mike. 2005. “A Note on the Adaptation.” In Don Carlos, xiii-xiv. London: Nick Hern. Rappaport, Helen. 2007. "Chekhov in the Theatre: The Role of the Translator in New Versions." In Voices in Translation: Bridging Cultural Divides, edited by Gunilla Anderman, 66-77. Clevedon: Multilingual Matters.

Robinson, Douglas. 2014. Western Translation Theory from Herodotus to Nietzsche. $2^{\text {nd }}$ ed. Abingdon: Routledge.

Ronder, Tanya. 2017. “The Roaming Art.” In Adapting Translation for the Stage, edited by Geraldine Brodie and Emma Cole, 203-209. Abingdon: Routledge.

Royal Court Theatre. 2016. “About Us." Accessed 7 January 2016. http://www.royalcourttheatre.com/about-us/.

St André, James. 2009. "Relay." In Routledge Encyclopedia of Translation Studies, $2^{\text {nd }}$ ed., edited by Mona Baker and Gabriela Saldanha, 230-232. Abingdon: Routledge.

Schiller, Friedrich. 2005. Don Carlos, in a version by Mike Poulton. London: Nick Hern.

Smith, Alistair. 2014. London Theatre Report. London: Society of London Theatre.

Sheffield Theatres. 2004. Don Carlos [Theatre Programme]. Sheffield: Sheffield Theatres.

Shuttleworth, Mark and Moira Cowie. 2014. Dictionary of Translation Studies. Abingdon: Routledge.

Society of London Theatre. 2017. Society Of London Theatre Reports Box Office Figures for 2016. Accessed 20 July 2017. http://solt.co.uk/about-london-theatre/pressoffice/society-of-london-theatre-reports-box-office-figures-for-2016/

Venuti, Lawrence. 2008. The Translator's Invisibility, $2^{\text {nd }}$ ed. Abingdon: Routledge.

Witt, Susanna. 2017. "Institutionalized Intermediates: Conceptualizing Soviet Practices of Indirect Literary Translation.” Translation Studies, 10:2, 166-182.

Woods, Michelle. 2012. Censoring Translation: Censorship, Theatre, and the Politics of Translation. London: Continuum. 